\title{
CARGO SECURING DURING TRANSPORTATION - USING EXTREME VALUES
}

\author{
Martin VLKOVSKÝ*, Luděk RAK*, Balázs TAKSÁS** \\ * University of Defence, Brno, The Czech Republic, \\ **National University of Public Service, Budapest, Hungary \\ martin.vlkovsky@unob.cz
}

\begin{abstract}
This article analyses possibilities for securing cargo on selected military truck - middle

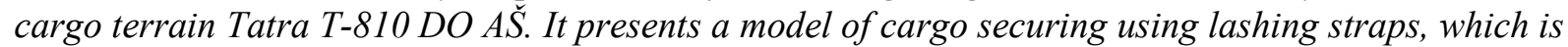
based on the minimum and maximum angle possible between lashing strap and horizontal plane where mounted. It compares inertial forces in the $x$-axis and y-axis, where the data source is in one case the basal variant of measured values of acceleration coefficients and in the second case normatively set values of acceleration coefficients. Both outputs - the size of the inertial forces in both axes are compared and a set of recommendations for cargo securing is formulated.
\end{abstract}

Keywords: transportation, cargo securing, acceleration coefficient, fastening strap

\section{Introduction}

Cargo securing on trucks is a key aspect of safe freight transportation. That argument applies not only in the civilian sector, but also in conditions of the Army of the Czech Republic (ACR). a Generally in military conditions the requirements for adequate lashing is all the more important that transportation itself is often undertaken in difficult conditions (eg. off-road). It can be assumed that the requirements for cargo securing in off-road conditions are significantly different, especially in relation to the action of the larger inertial forces during transportation.

Preliminary analysis, including statistical evaluation and usage of different methods of scientific work, shows that the differences are significant $[1,2,3,4,5]$. The key is the existence of extreme fluctuation of acceleration functions expressed with the highest, respectively the lowest values of acceleration coefficients in each axis.
Identification of different (in absolute value - higher) acceleration coefficient values than in European Standard EN 12195-1 (further "Standard"), was the subject of the above-mentioned work (see previous paragraph). However, those differences, especially those with values exceeding Standard, are only pre-requisite for the risks associated with improper cargo securing. Regarding the inclusion of the acceleration coefficients in more axes and other factors values are the key to compare potential risks - the size of the respective inertia forces.

The aim of this paper is primarily involve chosen (possible) extreme values demonstrated on a model that allows to illustrate differences in the size of the inertial forces acting on the cargo during transportation.

Acceleration coefficients values measured on $1^{\text {st }}$ June 2016 in a military training area Vyškov-Dědice in the Czech Republic are used as a data source. Transportation was undertaken on a paved road, which quality 
matches III. class roads. Those data offer a compromise between common road conditions and terrain conditions.

\section{Input data}

Input data were obtained during driver training attended by 14 drivers. Military truck - middle cargo terrain Tatra T-810 DO AS̆ with less than 34 thousands $\mathrm{km}$ driven and with $2,160 \mathrm{~kg}$ simulated cargo was used for the training. The measurements were performed with standard accelerometers from OMEGA
(OM-CP-ULTRASHOCK-5) [6].

The measuring provided 11,181 acceleration coefficient values in particular axes (designated $\mathrm{c}_{\mathrm{x}}, \mathrm{c}_{\mathrm{y}}$ and $\mathrm{c}_{\mathrm{z}}$ ) in total, which were then processed statistically [3]. Significant outputs, which make for creating a model in the following part of the article, include the values exceeding the Standard. Further acceleration function global extremes were identified in given axes, which serve to creating basal variants (see Table 1).

Table 1 - The largest measured fluctuations in particular axes

\begin{tabular}{|c|c|c|c|c|}
\hline Date & Time & $\begin{array}{c}\boldsymbol{x} \\
\text { Axis (g) }\end{array}$ & $\begin{array}{c}\boldsymbol{y} \\
\text { Axis (g) }\end{array}$ & $\begin{array}{c}\boldsymbol{z} \text { Axis } \\
(\mathbf{g})\end{array}$ \\
\hline $2016-06-01$ & $11: 18:$ & 5.50 & - & -6.75 \\
& 52 & & 1.74 & $(-5.75)$ \\
\hline $2016-06-01$ & $09: 24:$ & 3.40 & 2.28 & 5.35 \\
\hline
\end{tabular}

Note: The datalogger (accelerometer) recorded value of -6.75 $g$ for $z$-axis, however the value was measured not from zero but from the value of. Source: [3]

Basal variant determined using the extreme values of the measurement day can be written as follows:

$\mathrm{c}_{\max }=(5.50,-2.28,-5.75)$.

For statistical analysis only 8741 values were used, the rest represented stationary vehicle (breaks, changes of drivers).

From the results it is evident that considerable amount of values exceeds the value of $1 \mathrm{~g}$, stated in the Standard. In absolute numbers, this is 1,631 values, which represent $18.66 \%$ of the total number of values (excluding the stationary vehicle). Extremes were also identified, in total of 53 cases where the value of the respective acceleration coefficient exceeded $2 \mathrm{~g}$, representing $0.61 \%$ of the total number of values (excluding the vehicle is stationary) [3].

\section{Assumptions of Model}

For purposes of demonstration of significant values, to ensure safe cargo securing on the vehicle, a model of securing of standard handling unit (pallet unit) was created.
The model is created based on following premises:

Cargo is transported (secured) on the vehicle T-810 DO AS̆;

Cargo consists of the pallet unit, which has maximum height in accordance with the ČOS 399001 in the first case, ie. 1,600 mm [7], the minimum effective height corresponding to one layer of cargo with height of $100 \mathrm{~mm}$ on a plain wooden pallet with height of $150 \mathrm{~mm}$ in the second case; Cargo weight is $500 \mathrm{~kg}$ in both cases because of illustration of different angles;

Cargo (of the pallet units) is secured with lashing straps (the model does not serve for determining of required number or type of lashing straps) in both cases;

Simple wooden EUR pallets with standard dimensions $1200 \times 800 \mathrm{~mm}$ [8] is used to create a pallet unit;

Pallet units are positioned longitudinally toward the direction of the vehicle movement (x-axis) in both cases;

The highest, respectively the lowest values of acceleration coefficients, ie. data from Table 1 and values of acceleration coefficients indicated by the Standard, 
normatively given basal variant $\quad \mathrm{c}=$ $(0.80,0.60,1.00)$ [9] were used as a source of data;

The Calculation uses formula from the Standard.

For purposes of illustration both situations - securing of both pallet units - are shown

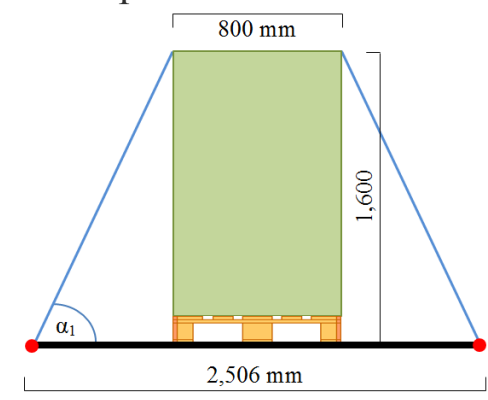

It is possible to easily determine the size of the angles $\alpha_{1}$ and $\alpha_{2}$ from the Figure 1, because the width of the cargo space of the relevant vehicle is known: $2,506 \mathrm{~mm}$, ie. distance of the heel of the pallet unit from the anchoring point $(k)$ is:

$(2,506-800) / 2=853 \mathrm{~mm}$

From there angle $\alpha_{1}$ can be easily determined using the appropriate trigonometric function using following formula:

$\operatorname{tg} \alpha_{1}=\mathrm{v}_{1} / \mathrm{k}$

where $v_{l}$ is height of the particular pallet unit. After substitution:

$\operatorname{tg} \alpha_{1}=1,600 / 853$

$\alpha_{1}=61,94^{\circ}$

Analogously angle $\alpha_{2}$, based on the different height of the pallet unit, can be determined, $\mathrm{k}$ remains the same.

$\operatorname{tg} \alpha_{2}=v_{2} / k$

where $v_{2}$ is height of the particular pallet unit. After substitution:

$\operatorname{tg} \alpha_{2}=250 / 853$

$\alpha_{2}=16,33^{\circ}$

Introduced sizes of angles which lashing strap contains with horizontal plane of the vehicle hull can be considered a maximum, respectively minimum possible with regard to the requirements of relevant legislation limitations on the part of (cargo) containers and the pallet height. in Figure 1. The key point for the calculation is the angle $\alpha$, ie. angle that the lashing strap contains with the horizontal plane of the vehicle hull.

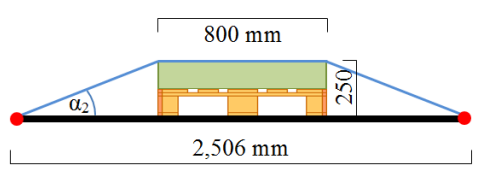

Figure 1 - Securing of model palles units

\section{Securing model with usage of chosen extremes}

The object of the model is to prove the hypothesis, that securing method, which is demonstrated with angles $\alpha_{1}$ and $\alpha_{2}$ in the model, significantly affects the resulting inertia force acting on the cargo. For calculation purposes the following formula set in the Standard is used [9]:

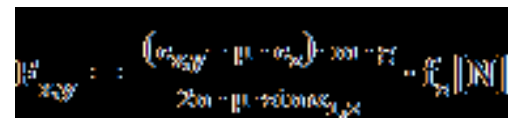

where $F_{x, y}$ are searched sizes of tension forces, $c_{x}, c_{y}$ and $c_{z}$ are values of acceleration coefficients in the respective axes, $\mu$ is the friction coefficient, $m$ is mass of cargo, $g$ is gravitational acceleration, $f_{s}$ is safety factor, $n$ is number of lashing straps (for the purposes of the model $n=1$ ) and the angles $\alpha_{1}$ and $\alpha_{2}$ are the angles calculated above.

The specific input values for substitution into the formula are shown in Table 2. For clarity, sizes of inertial forces in $\mathrm{x}$ and $y$ axes will be searched. According to the Standard the z-axis value is usually not introduced, because it can be implicitly regarded as the least important for the method of securing $\left(\mathrm{F}_{\mathrm{z}}\right)$, ie. its value is the smallest and it is anticipated that the following applies:

$$
\mathrm{F}_{\mathrm{z}}<\mathrm{F}_{\mathrm{x}} \wedge \mathrm{F}_{\mathrm{y}}<\mathrm{F}_{\mathrm{z}}
$$


Table 2 - Input values of the model

\begin{tabular}{|l|l|l|l|l|}
\hline $\begin{array}{c}|c| \\
\text { ariable }\end{array}$ & $\begin{array}{c}\text { Value } \\
(\text { norm })\end{array}$ & $\begin{array}{c}\text { Value } \\
\text { (extremes) }\end{array}$ & nit & \multicolumn{1}{c|}{ Note } \\
\hline $\mathrm{F}_{\mathrm{n}}$ & $?$ & - & $\mathrm{N}$ & Tension force (norm) \\
\hline $\mathrm{F}_{\mathrm{e}}$ & - & $?$ & $\mathrm{~N}$ & Tension force (extremes) \\
\hline $\mathrm{c}_{\mathrm{x}}$ & 5.5 & 0.8 & - & Acceleration coefficient $(\mathrm{x})$ \\
\hline $\mathrm{c}_{\mathrm{y}}$ & -2.28 & 0.6 & - & Acceleration coefficient $(\mathrm{y})$ \\
\hline $\mathrm{c}_{\mathrm{z}}$ & -5.75 & 1.0 & - & Acceleration coefficient $(\mathrm{z})$ \\
\hline$\mu$ & 0.4 & 0.4 & - & Friction coefficient \\
\hline $\mathrm{m}$ & 500 & 500 & $\mathrm{~kg}$ & Mass of cargo \\
\hline $\mathrm{g}$ & 9.81 & 9.81 & $\mathrm{~ms}^{-2}$ & Gravitational acceleration \\
\hline $\mathrm{f}_{\mathrm{s}}$ & 1.25 & 1.25 & - & Safety factor \\
\hline $\mathrm{n}$ & 1 & 1 & $\mathrm{pc}$ & Number of lashing straps \\
\hline$\alpha_{1}$ & 61.94 & 61.94 & $\circ$ & Angle - strap contains with floor \\
\hline$\alpha_{2}$ & 16.33 & 16.33 & $\circ$ & Angle - strap contains with floor \\
\hline
\end{tabular}

To distinguish between inertial forces (in given axes $-x, y$, for given angles $\alpha_{1}$, $\alpha_{2}$ ) this designation is used:

$F_{n x 1}$ - for Standard values, x-axis and angle $\alpha_{1}$,

$F_{n y l}$ - for Standard values, y-axis and angle $\alpha_{1}$,

$F_{n x 2}$ - for Standard values, x-axis and angle $\alpha_{2}$,

$F_{n y 2}$ - for Standard values, y-axis and angle $\alpha_{2}$,

$F_{e x l}$ - for extreme values, $\mathrm{x}$-axis and angle $\alpha_{l}$,

$F_{e y 1}$ - for extreme values, y-axis and angle $\alpha_{1}$,

$F_{e x 2}$ - for extreme values, $\mathrm{x}$-axis and angle $\alpha_{2}$,

$F_{e y 2}$ - for extreme values, y-axis andangle $\alpha_{2}$.

The results after substitution for individual variations are presented in Table 3 .
From the results in Table 3 it is obvious that the angle during securing is an important aspect affecting the size of the resulting inertia forces. Therefore, in both cases for $\mathrm{x}$-axis and $\mathrm{y}$-axis the ratio between forces is 1:3 in favour of the larger angle. The ratio between the angles is slightly smaller, the size of angle $\alpha_{2}$ corresponds to about $26 \%$ of the angle $\alpha_{1}$.

As a more important factor the acceleration coefficient values, their ratio, and last but not least, the direction (designated with sign plus or minus) may be regarded.

Generally, it should stand that the Standard is quite little strict and the values are not suitable for transportation over poor surfaces - roads. Values assume the transportation especially over the roads of the highest class and highways. With abstracting from isolated bigger fluctuations - shocks (especially in the $\mathrm{z}$-axis). Forces sizes using the acceleration coefficient values of the Standard are really very small and do not exceed a few hundred Newtons. 
Table 3 - Values of the inertia forces and their ratios

\begin{tabular}{|c|c|c|c|c|c|}
\hline $\begin{array}{l}\text { Variable } \\
\text { - norm }\end{array}$ & alue $^{V}$ & nit & $\begin{array}{l}\text { Variable - } \\
\text { extremes }\end{array}$ & alue $^{V}$ & nit \\
\hline$\left.c_{x}, \alpha_{1}\right) F_{n x l} \quad($ for & $\begin{array}{r}4 \\
33\end{array}$ & & $F_{\text {exl }}\left(\right.$ for $\left.c_{x}, \alpha_{1}\right)$ & $\begin{array}{r}8 \\
, 440\end{array}$ & \\
\hline$\left.c_{y}, \alpha_{1}\right) F_{n y 1} \quad($ for & $\begin{array}{r}2 \\
16\end{array}$ & & $F_{e y 1}\left(\right.$ for $\left.c_{y}, \alpha_{1}\right)$ & 2 & \\
\hline$\left.c_{x}, \alpha_{2}\right) F_{n x 2} \quad($ for & $\begin{array}{r}1 \\
38 \\
\end{array}$ & & $F_{e x 2}\left(\right.$ for $\left.c_{x}, \alpha_{2}\right)$ & $\begin{array}{r}2 \\
, 689 \\
\end{array}$ & \\
\hline$\left.c_{y}, \alpha_{2}\right) F_{n y 2} \quad($ for & $\begin{array}{l}6 \\
9\end{array}$ & & $F_{e y 2}\left(\right.$ for $\left.c_{y}, \alpha_{2}\right)$ & 7 & \\
\hline$F_{n x 1}: F_{n x 2}$ & 3 & & $F_{e x 1}: F_{e x 2}$ & 3 & \\
\hline$F_{n y 1}: F_{n y 2}$ & 3 & & $F_{e y 1}: F_{e y 2}$ & 3 & \\
\hline
\end{tabular}

The situation is more interesting for the particular measured values of the acceleration coefficients in each axis. In this case is it obvious that while the $\mathrm{x}$-axis the values are higher - several thousand Newtons $(2,689$, resp. 8,440), in the $y$-axis due to the different signs of individual acceleration coefficients the inertial forces were almost cancelled out. Absolutely negligible inertial forces in the $y$-axis for both angles $\left(\mathrm{F}_{\text {ey1 }}, \mathrm{F}_{\text {ey2 }}\right)$ are the result. For the highest calculated values can be stated that the pallet unit weighing $500 \mathrm{~kg}$ "behaves" like a cargo weighing $844 \mathrm{~kg}$.

Assuming using values of the acceleration coefficients for the basal variation in the absolute values, the inertial force would be cancelled out and the resulting values of inertial forces in the individual axes would be significantly greater.

\section{Conclusion}

The present paper illustrates the differences in the effect of inertial forces to transported cargo in the context of usage of different input data. The above-defined model implies that the angle that lashing strap contains with the horizontal plane of the vehicle hull is important for the final size of the inertial forces, as well as different sizes of the respective acceleration coefficients and their signs. Input data and their evaluation also show that despite the measurement in terms of the paved road (ie. not in the off-road conditions), the global extremes of the measured function of the acceleration coefficients can pose risk. The risk arises from the significant impact of such values on the final size of the inertial forces acting on the cargo, which may not be always cancelled out, but rather multiplied.

Prerequisite for further research is to create a sufficient data sample that enables to generalize and unambiguously verify the presented partial conclusions. The data sample should respect primarily different types of vehicles, different road surface, and differences among individual drivers.

The overall objective of the research is to develop a concept of basal variants of the acceleration coefficients in each axis, which would be useful for ACR in various conditions. Basal variants should reflect primarily the extremes in off-road conditions and specifics of lower classes roads (II and III. class).

\section{References}

[1] Vlkovský, M. a kol. Přepravní experiment - Komparace vybraných dopravních cest. Economics and Management, 2016, č. Zvláštní číslo, s. 100-104. ISSN 1802-3975.

[2] Vlkovský, M. et al. Přeprava v terénu a zajištění nákladu. Crede Experto: transport, society, education, language, 2016, No. 2 (9). ISSN 2312-1327. 
[3] Vlkovský, M. et. al. The Cargo Securing Based on European Standards and its Applicability in Off-road Transport Conditions. In: ICTTE Proceedings, p. 603-607, Belgrade, Serbia, 2016.

[4] Grzesica, D., Parkitny, W. The Use of Forecasting Models to Identify Trends of Logistics Development in Business Management. International Journal of Contemporary Management, Vol. 15, No. 2, p. 105-122, 2016.

[5] Grzesica, D., Wiecek, P. Advanced Forecasting Methods Based on Spectral Analysis. In: WMCAUS Procedia Engineering. p. 256-258, Prague, Czech Republic, 2016.

[6] Omega. Accelerometer - Data logger. [online]. 2015. [vid. 2017-03-13]. Available from WWW: http://www.omega.com/das/pdf/OM-CP-ULTRASHOCK.pdf.

[7] ČOS 399 001. Manipulace s materiálem v poli. 4. vyd., Úř OSK SOJ, Praha, 56 s, 2012.

[8] ČOS 399 006. Vojenské palety, baleni a kontejnery. 3. vyd., Úř OSK SOJ, Praha, 52 s, 2017.

[9] EN 12195-1. Load restraining on road vehicles - Safety - Part 1: Calculation of securing forces. Czech Office for Standards, Metrology and Testing, Prague, 48 p, 2011. 